\title{
New-onset complete right bundle branch block following successful balloon mitral valvuloplasty for mitral stenosis: a new phenomenon?
}

\author{
Barun Kumar, ${ }^{1}$ Ashwin Kodliwadmath 다, ${ }^{1}$ Anupam Singh, ${ }^{2}$ Bhanu Duggal ${ }^{1}$
}

${ }^{1}$ Cardiology, All India Institute of Medical Sciences, Rishikesh, Uttarakhand, India ${ }^{2}$ Ophthalmology, All India Institute of Medical Sciences, Rishikesh, Uttarakhand, India

\section{Correspondence to} Dr Ashwin Kodliwadmath; ashrocks33@gmail.com

Accepted 5 January 2020
Check for updates

(c) BMJ Publishing Group Limited 2020. No commercial re-use. See rights and permissions. Published by BMJ.

\footnotetext{
To cite: Kumar $B$, Kodliwadmath A, Singh A, et al. BMJ Case Rep 2020;13:e232930. doi:10.1136/bcr-2019232930
}

\section{DESCRIPTION}

We report a case of a 27-year-old man with no history of rheumatic fever who presented with a slowly progressive breathlessness and fatigue. $\mathrm{He}$ had progressed from New York Heart Association class II to class III over 8 months, with episodes of paroxysmal nocturnal dyspnoea for the past 1 month. Cardiovascular system examination revealed tapping apex beat in the left fifth intercostal space, loud S1, opening snap (OS), short A2-OS interval and grade 3 mid-diastolic murmur at the apex. Baseline 12-lead ECG showed left atrial abnormality (enlargement) with incomplete right bundle branch block (RBBB) (figure 1A). Transthoracic echocardiography revealed severe mitral stenosis (MS), with mitral valve area (MVA) of $0.734 \mathrm{~cm}^{2}$ by planimetry and $0.76 \mathrm{~cm}^{2}$ by pressure half-time (normal 4-6 $\mathrm{cm}^{2}$ ), mean gradient (MG) of 6 , peak gradient $(\mathrm{PG})$ of 14 through the mitral valve and trivial mitral regurgitation (MR) (figure 1B-D). The Wilkins' score was calculated showing calcification up to the mid-leaflet ( 3 points), mid-leaflet thickening ( 2 points), decreased mobility in the mid-portion and base of the leaflets ( 2 points), and minimal chordal thickening (1 point). The total Wilkins' score was 8 .

Although there was no history of rheumatic fever, the morphological characteristics of the mitral valve on echocardiography-fixed posterior mitral leaflet, doming anterior mitral leaflet, commissural fusion and chordal thickening-in the presence of severe MS led us to diagnose the aetiology of MS as rheumatic. It is well known that $50 \%$ of cases of rheumatic heart disease do not have a history of rheumatic fever. ${ }^{1}$

Transoesophageal echocardiography ruled out left atrial appendage clot. After written informed consent, balloon mitral valvuloplasty (BMV) was performed through the right femoral route using the Inoue balloon technique on the same day 2 hours after taking baseline ECG (figure 2A). Intraprocedural rhythm monitoring was done with single lead II ECG; however, 12-lead ECG was not done during the procedure. After the procedure, the patient had no breathlessness, chest pain or palpitations. The 12-lead surface ECG done $10 \mathrm{~min}$ after BMV and after shifting to the cardiac care unit showed the development of complete RBBB, indicating probable intraprocedural development of complete RBBB (figure 2B). Post-BMV echocardiography done $20 \mathrm{~min}$ after BMV showed moderate MS (MVA $1.5 \mathrm{~cm}^{2}$; normal 4-6 $\mathrm{cm}^{2}$ ), PG of 7, MG of 3, mild MR and no residual atrial septal defect (ASD). Serial ECG monitoring was done every $30 \mathrm{~min}$ for 2 hours and then hourly for 6 hours and showed persistence of complete RBBB with no dynamic changes. The patient improved symptomatically and was discharged the next day. Follow-up after 1 week still revealed complete RBBB on ECG with improvement in symptoms.

BMV is the treatment of choice for severe MS with Wilkins' score $\leq 8$. BMV can have complications such as severe MR, cardiac perforation leading to haemopericardium and cardiac tamponade, embolic events including stroke, access site complications, arrhythmias, and residual ASD. ${ }^{2}$ Iatrogenic RBBB has been described after cardiac transplantation, coronary artery bypass graft surgery, right heart catheterisation, intracardiac repair of the tetralogy of Fallot, surgery for double outlet right ventricle, surgery for complete atrioventricular canal defect, alcohol septal ablation for hypertrophic obstructive cardiomyopathy and after closure

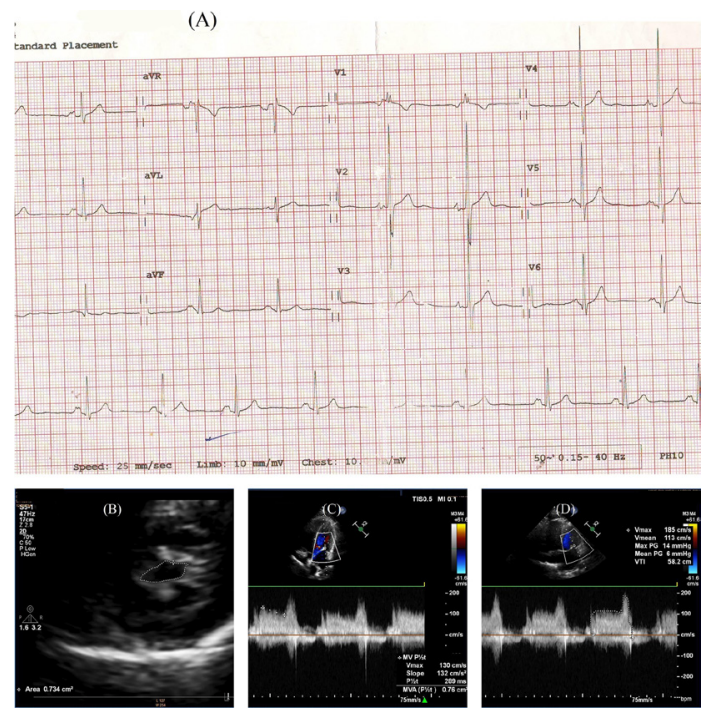

Figure 1 (A) Pre-BMV 12-lead ECG showing left atrial abnormality and incomplete right bundle branch block. (B) Transthoracic echocardiography in parasternal shortaxis view at the level of the mitral valve showing mitral valve area of $0.73 \mathrm{~cm}^{2}$ by planimetry. (C) Transthoracic echocardiography showing calculated mitral valve area (MVA) of $0.76 \mathrm{~cm}^{2}$ by pressure half-time method. (D) Transthoracic echocardiography showing peak gradient (PG) of $14 \mathrm{~mm} \mathrm{Hg}$ and mean gradient of $6 \mathrm{~mm} \mathrm{Hg}$ through the mitral valve. BMV, balloon mitral valvuloplasty; Vmax, maximum velocity; $V$ min, mean velocity. 

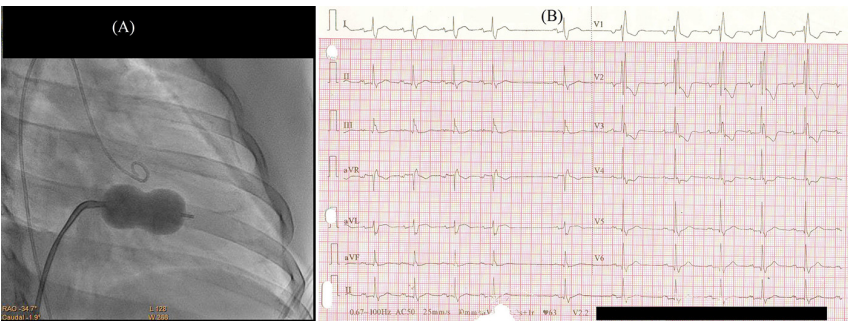

Figure 2 (A) Fluoroscopy image in RAO caudal view showing balloon dilatation of the mitral valve. (B) Post-BMV 12-lead ECG showing left atrial abnormality and presence of complete right bundle branch block. $\mathrm{BMV}$, balloon mitral valvuloplasty; RA0, right anterior oblique.

of ventricular septal defect. ${ }^{3-9}$ To the best of our knowledge, new onset or progression of RBBB following BMV has not been described in the literature. The presence of RBBB on ECG in a patient with MS indicates severe MS and widespread calcification on the valve. ${ }^{10}$ Also, catheter manipulation across the valve can dislodge the calcification and spread it along the right bundle branch during catheter withdrawal, which could result in the progression of incomplete RBBB to complete RBBB following $\mathrm{BMV}$, as in our case. Other potential mechanisms include large iatrogenic ASD and anatomical variation in the conduction pathways resulting in trauma during catheter manipulation. Organic rheumatic tricuspid valve disease in association with MS can also result in the spread of calcification to the adjacent right bundle

\section{Learning points}

Although various structural heart disease procedures cause right bundle branch block (RBBB), iatrogenic RBBB following balloon mitral valvuloplasty (BMV) has not been described in the literature.

- The mechanism of RBBB post-BMV is elusive but can be due to dislodgement and spread of calcification from the valve to the right bundle branch during catheter manipulation.

- Other potential mechanisms include large iatrogenic atrial septal defect, anatomical variation in the conduction pathways resulting in trauma during catheter manipulation, spread of calcification from associated adjacent organic tricuspid valve disease, or as yet unclear mechanisms.

- In a patient with severe mitral stenosis undergoing BMV, especially with pre-existing left bundle branch block on ECG, the possibility of the development of complete heart block due to rare occurrence of RBBB should always be anticipated, and a temporary pacemaker can be used prophylactically or be immediately available should it be required. branch, causing RBBB. The occurrence of complete RBBB in this case was rare and unexpected. If the RBBB had developed in the background of pre-existing left bundle branch block (LBBB), the patient would have developed complete heart block (CHB) requiring temporary pacing. ${ }^{11}$ If the $\mathrm{CHB}$ did not resolve, the patient would have needed permanent pacing. Thus, adequate precautions and patient counselling are a must before performing BMV in a patient with pre-existing LBBB on ECG.

Whether complete RBBB can develop only in patients with incomplete RBBB at baseline or even without incomplete RBBB is not known. Long-term follow-up of patients can determine whether this complete RBBB will resolve with time or remain persistent. This case report is the first description of RBBB following BMV and gives us a new phenomenon which paves the road towards further studies that can elucidate the mechanism.

Contributors $A K$ and $B K$ : conception. $A S$ and $B K$ : case report. BD and $A K$ : investigations. BD and AS: discussion. AK and BD: critical appraisal.

Funding The authors have not declared a specific grant for this research from any funding agency in the public, commercial or not-for-profit sectors.

Competing interests None declared.

Patient consent for publication Obtained.

Provenance and peer review Not commissioned; externally peer reviewed.

ORCID iD

Ashwin Kodliwadmath http://orcid.org/0000-0002-1709-3579

\section{REFERENCES}

1 Kumar RK, Tandon R. Rheumatic fever \& rheumatic heart disease: the last 50 years. Indian J Med Res 2013;137:643-58.

2 Nobuyoshi M, Arita T, Shirai S-ichi, et al. Percutaneous balloon mitral valvuloplasty. Circulation 2009;119:e211-9.

3 Surawicz B, Knilans T. Right bundle branch block. In: Surawicz B, Knilans TK, eds. Chou's electrocardiography in clinical practice. 6th edn. Philadelphia: Elsevier, 2001: 95-107

4 Okoroma EO, Guller B, Maloney JD, et al. Etiology of right bundle-branch block pattern after surgical closure of ventricular-septal defects. Am Heart J 1975;90:14-18

5 Talreja DR, Nishimura RA, Edwards WD, et al. Alcohol septal ablation versus surgical septal myectomy: comparison of effects on atrioventricular conduction tissue. J Am Coll Cardiol 2004;44:2329-32.

6 Gelband H, Waldo AL, Kaiser GA, et al. Etiology of right bundle-branch block in patients undergoing total correction of tetralogy of Fallot. Circulation 1971:44:1022-33.

7 Golshayan D, Seydoux C, Berguer DG, et al. Incidence and prognostic value of electrocardiographic abnormalities after heart transplantation. Clin Cardiol 1998;21:680-4.

8 Miura M, Shirai S, Uemura Y, et al. Clinical impact of intraventricular conduction abnormalities after transcatheter aortic valve implantation with Balloon-Expandable valves. Am J Cardiol 2019;123:297-305.

9 Mandal KD, Su D, Pang Y. Long-Term outcome of transcatheter device closure of Perimembranous ventricular septal defects. Front Pediatr 2018;6:128.

10 Ocal A, Yildirim N, Ozbakir C, et al. Right bundle branch block: a new parameter revealing the progression rate of mitral stenosis. Cardiology 2006;105:219-22.

11 Wani AS, Fasanya A, Kalamkar P, et al. latrogenic transient complete heart block in a preexisting LBBB. Case Rep Crit Care 2016;2016:1-3. 
Copyright 2020 BMJ Publishing Group. All rights reserved. For permission to reuse any of this content visit https://www.bmj.com/company/products-services/rights-and-licensing/permissions/

BMJ Case Report Fellows may re-use this article for personal use and teaching without any further permission.

Become a Fellow of BMJ Case Reports today and you can:

- Submit as many cases as you like

- Enjoy fast sympathetic peer review and rapid publication of accepted articles

Access all the published articles

Re-use any of the published material for personal use and teaching without further permission

Customer Service

If you have any further queries about your subscription, please contact our customer services team on +44 (0) 2071111105 or via email at support@bmj.com.

Visit casereports.bmj.com for more articles like this and to become a Fellow 